"Ownership structure, organization stability and biotechnology company performance"

Ting-Yi Cheng
Hung-Cheng Lai

ARTICLE INFO

Ting-Yi Cheng and Hung-Cheng Lai (2016). Ownership structure, organization stability and biotechnology company performance. Investment Management and Financial Innovations, 13(2), 109-116. doi:10.21511/imfi.13(2).2016.12

DOI http://dx.doi.org/10.21511/imfi.13(2).2016.12

RELEASED ON Friday, 03 June 2016

JOURNAL

"Investment Management and Financial Innovations"

FOUNDER

LLC "Consulting Publishing Company "Business Perspectives"

NUMBER OF REFERENCES

0

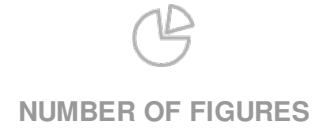

0

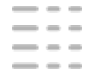

NUMBER OF TABLES

0

(c) The author(s) 2023. This publication is an open access article. 
Ting-Yi Cheng (Taiwan), Hung-Cheng Lai (Taiwan)

\title{
Ownership structure, organization stability and biotechnology company performance
}

\begin{abstract}
In this paper, the authors use the method of quantile regression to analyze the effect of different ownership structure and organization stability on the performance of biotechnology company. Data from the 2004 and 2015 Taiwan listed biotechnology companies are the research samples to find out the relationship of ownership structure, organization stability and corporate performance. The results show that the ownership structure and the organization stability have a positive effect on firm performance.
\end{abstract}

Keywords: ownership structure, organization stability, biotechnology company.

JEL Classification: G31, G34.

\section{Introduction}

As the world countries gradually enter an aging society, the biotechnology pharmaceutical industry has become a new bright global business in the 21 st century. Taiwan government has identified the biotechnology pharmaceutical industry as one of the ten emerging industries. However, many companies in Taiwan are facing a new market structure and new challenges that industries lack of natural resources and the environment changes rapidly. Therefore, biotech industry corporate governance is more worthy to attention.

In today's environment filled with many diseases and viruses which increase number of patients, the market is facing drug shortages that not only have a positive impact on the biotech industry, but also promote the development of the industry. Comparison with the Taiwan Weighted Stock Index trends shows the characteristic that Taiwan's biotech pharmaceutical technology index lively than the Taiwan stock market volatility (Figure 1). In recent years, countries around the world are strongly promoting the knowledge economy. As the biotech industry has a long development time, high regulatory barriers and the huge funds invested, Taiwanese government realized the biotech industry required immediate early layout. Until September 2013 , biotech business has 88 , and the investment rate of return on biotech industry by National Development Fund is very amazing, a total value of $\$ 28.86$ billion profit up nearly six-fold. It can be seen in the development of Taiwan's biotech industry for future growth can be expected.

Moreover, the gap between rich and poor countries has gradually expanded, Taiwan has become the Mtype society. According to Taiwan's CEPD

(C) Ting-Yi Cheng, Hung-Cheng Lai, 2016.

Ting-Yi Cheng, Department of Finance, Overseas Chinese University, Taiwan.

Hung-Cheng Lai, corresponding author, Department of Finance, Overseas Chinese University, Taiwan. estimate, in 2017 , the elderly population will be over $14 \%$. To 2060 , the population aged 65 or older from the current $10.7 \%$ to $41.6 \%$, becoming an aging society. This trend is bound to make the rising number of chronic diseases, as well as to improve the relevance of drug demand, means that the government will also increase the budget for health care related indirectly promote industrial development.

Under the Government's active promotion, the biotech industry also should identify the appropriate self-management to enhance competitiveness and maintain the sustainable development of the industry to become competitive foundation for the future. Therefore, if the biotech industry companies could understand the company's governance, and find solutions to improve the business, and strengthen the body, the company will have the ability to enhance the competitiveness of enterprises.

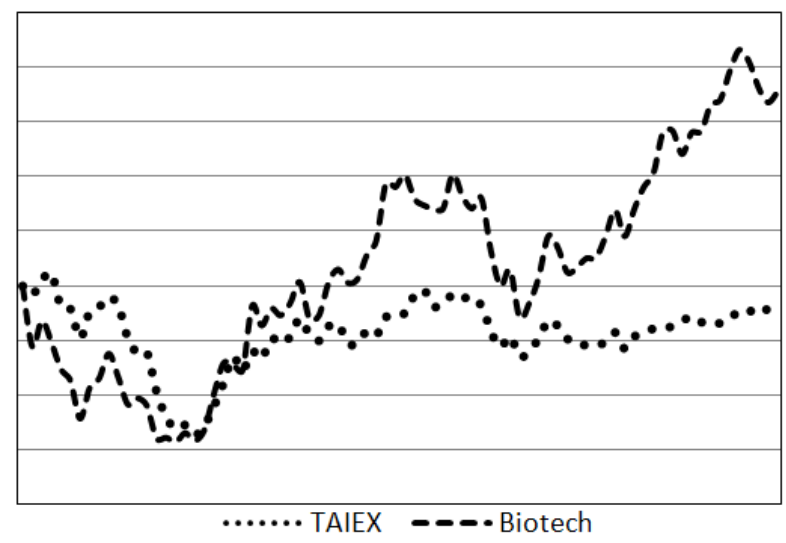

Fig. 1. TAIEX and Biotechnology Index Chart

The biotechnology company is a unique industry in Taiwan which most of them have no revenue. Their clinical trials spent a large of cost on $R \& D$ each year that is an essential part of the drug development process. This means that, with the biotechnology company clinical trials, some may have the outcome and some may not. In other words, traditional financial statement information through financial ratio analysis and accounting ratio 
analysis is not easy to represent the true value of the biotechnology company. Therefore, since corporate governance provides the framework for attaining a company's objectives and encompasses practically every sphere of management, it is important to investigate the role of corporate governance in the biotechnology company.

In view of this, the biotech industry is a special case from other industry that is worth to study. Previous studies rarely use biotech industry to explore the relationship among ownership structure, organization stability and biotechnology company performance. Thus, we use biotech pharmaceutical companies as samples, which has been listed in Taiwan OTC stock market. The research shows that the ownership structure and the organization stability have a positive effect on firm performance.

\section{Literature review}

Since corporate governance has gained increasing attention from the negative variety of measures of corporate governance into a positive tool to create profits, the implementation of better corporate governance will receive a higher stock price. Kim, Lee, Lee and Kim (2010) suggest that sustainability reporting can communicate to employees that firms are being socially responsible. Besides, good corporate governance has been found to lead to higher employees' morale, commitments and job satisfactions. However, Litvak (2007) found that during announcements relating to the implementation of SOX, the stock prices of SOXexposed foreign firms significantly declined. Ang, Cole and Lin (1999) and Singh and Davidson (2003) also pointed out that, with respect to insiderdominated board of directors, external board members less able to reduce agency costs. Barnhart and Rosenstein (1998) pointed out that to improve the ratio of insider ownership will make insider profits and company value tends to be consistent, so as to reduce agency costs. McConnell and Servaes (1990) also made a similar empirical research. When the ratio of managerial holdings is reached a certain level could help enhance the company's performance. The empirical research of Han and Suk (1998) shows that managers should not be allowed high shareholding ratio that may generate agency costs and in poor performance of the company, which high managerial ownership have negative impact on corporate performance.

In view of business performance discussion, Rechner and Dalton (1991) consider CEO duality affect the independence of the Board of Directors and supervision of corporate governance. In addition, Black, Jang and Kim (2003) considered a higher standard of corporate governance companies are significantly higher than the low standard in both Tobin's Q and the price to book value ratio. Weir, Laing and McKnight (2002) used 311 quoted, non-financial UK companies covering the period 1994-1996 and found that firms are in sectors where takeover intensity is high trade at higher market values relative to book value.

In terms of board structure, Harjoto and Jo (2011) find that firms use governance mechanisms, along with CSR engagement, to reduce conflicts-of-interest between managers and non-investing stakeholders. Their results also pointed out that CSR engagement positively influences operating performance and firm value, supporting the conflict-resolution hypothesis as opposed to the over-investment and strategic choice arguments. Millestein and MacAvoy (1998) found that higher corporate governance relatively good average performance. In addition, Minor and Morgan (2011) find that firms with higher CSR ratings fare better than those that do not. Moreover, a firm that is exceptional in both doing well and avoiding harm suffered virtually no reputational damage following events.

The previous literature argues that family management also has to be considered. La Porta et al. (1999) emphasized the importance of family ownership on corporate structure. They find that family-owned firms represented from $20 \%$ of the sample in the US up to $40 \%$ in the UK and $60 \%$ to $80 \%$ in Italy. Countries like Argentina, Hong Kong, Israel, Mexico, and Sweden all had a share of family-owned firms higher than $50 \%$. Villalonga and Amit (2006) show that the value of firm is high when it is managed by the founder and low when managed by a descendant. Yeh and Woidtke (2005) also examine entrenchment that focuses on Taiwanese publicly traded firms in the composition of the board of directors. They find that corporate governance is worse when the board is affiliated in family-controlled firm, but better when the board is dominated by members who are not so affiliated.

Due to the corporate governance establishes who holds the legal power within the organization, Kelton and Yang (2008) suggest that corporate governance will affect the company's information transparency, because the agency costs of both investors and managers arising from asymmetric information. However, McConnell, Servaes and Lins (2008) find no evidence to support these interpretations that insider purchases are a response to changes in firm characteristics that require a new optimal equilibrium ownership level ${ }^{1}$.

\footnotetext{
${ }^{1}$ See, for example He, Zhang and Wang (2015).
} 
On the other hand, Cerbionia and Parbonettia (2007) examine the relationship between governance variables and voluntary intellectual capital disclosure in a sample of European biotechnology firms. There results suggest that governance-related variables strongly influence the quantity of information disclosed. In regard to the quality of disclosure, the results show that the proportion of independent directors is positively related to the disclosure of internal structure. Furthermore, CEO duality is negatively linked to the disclosure of forward-looking information, and board structure helps to improve the annual report's overall readability.

Regarding the research methods of the biotechnology company, Lacetera (2001) focus on some determinants of firms' strategy and performance in the pharmaceutical industry and point out that various dimensions are involved in evolution, and highlighted the emergence of new organizational practices to deal with different research methods. The result shows that the convergence of traditional and more recent theorizing on corporate governance, and the adoption of theoretical tools from other field of industrial economics, is the appropriate pattern.

\section{Research method}

2.1. Variable definitions. We used data from the 2004 and 2015 Taiwan listed biotechnology companies as the research samples to find out the relationship of ownership structure, organization stability and corporate performance. The samples exclude the company with merge and liquidation to avoid those samples. Furthermore, in order to compare the same period of time, we also eliminate the full-cash delivery stocks, preferred stocks, warrant sand beneficiary certificates and financial insurance sector. Relevant data from this study are sourced from Taiwan Economic Journal (TEJ), including abnormal return $(A R), \mathrm{ROE}, \mathrm{P} / \mathrm{B}$ ratio $(P B R)$, the variables are manager stock holding $(M R H)$, natural persons' holding $(N P H)$, domestic financial institutions' holding $(L F I)$, foreign financial institutions' holding $(F F I H)$, major shareholders holding (MSH), board members' holding (BMH), directors and supervisors' stock pledged ratio $(D S P)$, board chairman turnover $(B C T)$, CEO turnover (CEOT), financial management turnover (FIT) and employment turnover rate (ETR). Table 1 shows the definitions of variables computed from these data.

Table 1. The definitions of variables

\begin{tabular}{|c|c|}
\hline Variables & Definitions \\
\hline \multicolumn{2}{|l|}{ Corporate performance } \\
\hline$A R$ & $\begin{array}{l}\text { Abnormal return = actual return }- \text { expected return } \\
\text { (The difference between the actual return of a stock and the expected return) }\end{array}$ \\
\hline ROE & $\begin{array}{l}\text { Return on equity = net income/shareholder's equity } \\
\text { (ROE reveals how much profit a company generates with the shareholders have invested in the company) }\end{array}$ \\
\hline PBR & $\begin{array}{l}P / B \text { ratio= stock price / book value } \\
\text { (Measure of the share price relative to the value of the company's total assets minus total liabilities) }\end{array}$ \\
\hline \multicolumn{2}{|l|}{ Ownership structure } \\
\hline MRH & Manager stock holding \\
\hline $\mathrm{NPH}$ & Natural persons' holding \\
\hline LFI & Domestic financial institutions' holding \\
\hline FFIH & Foreign financial institutions' holding \\
\hline MSH & Major shareholders holding over $5 \%$ \\
\hline$B M H$ & Board members' holding \\
\hline$D S P$ & Directors and supervisors' stock pledged ratio \\
\hline \multicolumn{2}{|l|}{ Organization stability } \\
\hline$B C T$ & Board chairman turnover \\
\hline CEOT & CEO turnover \\
\hline FIT & Financial management turnover \\
\hline ETR & Employment turnover rate \\
\hline
\end{tabular}

2.2. Panel quantile regression models. An ordinary least squares (OLS) model is based on the mean of the conditional distribution of the dependent variable. However, it may be of interest to know the effects of the exogenous variables at different points of the conditional distribution of the dependent variable. The advantage of (quantile regression, QR) is that, while OLS can be inefficient, if the errors are highly non-normal, QR is more robust to outliers and nonnormal errors. The previous literature is mostly based on the assumption of normal distribution. QR method can provide a more nuanced analysis than is feasible with OLS in quantitative investment analysis.

Koenker and Bassett (1978) estimate conditional quantiles of a response variable $Y$, given regressors $X$. The quantile regression model can be written as: 


$$
Y=\beta X+\varepsilon \quad \text { with } \operatorname{Quant}(Y)=\beta X,
$$

where $X_{i}$ denotes the vector of exogenous variables and $\beta$ is the vector of estimated parameters at quantile $\tau$. Quant $_{\theta}(Y)$ denotes the $\tau$ th conditional quantile of the $Y$ given $X$. The $\tau$ th regression quantile, $0<\tau<1$, is defined as a solution to the problem:

$\min _{\hat{\beta}}\left[\tau \sum_{Y_{i} \geq \hat{\beta} x}\left|Y_{i}-\hat{\beta} x\right|+(1-\tau) \sum_{\mathrm{Y}_{\mathrm{i}}<\hat{\beta} \mathrm{x}}\left|\mathrm{Y}_{\mathrm{i}}-\hat{\beta} \mathbf{x}\right|\right]$.

The special case $\tau=0.5$ is equivalent to median regression. $\tau=0.1,0.3,0.5,0.7,0.9$ conditional quantile functions estimated by the kernel-based estimator described in the previous section. Both of the input and the output variables are standardized in $[0,1]$.

QR also provides a more abundant characterization of the data, allowing us to consider the impact of a covariate on the entiredistribution of $y$, not merely its conditional mean.

There is a related literature on non-separable panel data models. For example, Chernozhukov, Fernandez-Val, Hahn and Newey (2010) and Canay (2011) show that the quantile treatment effect of interest is partially identified (for fixed $\mathrm{T}$ ) and provide bounds for those effects in the model 1:

$Y_{i, t}=g_{0}\left(X_{i, t}, \eta_{i}, U_{i, t}\right)$,

$U_{i, t} / X_{i}, \eta_{i}={ }^{d} U_{i, t^{\prime}} / X_{i}, \eta_{i}$,

where $X_{i t}$ is assumed discrete. They also derive rates of shrinkage of the identified set to a point as $\mathrm{T}$ goes to infinity.

2.3. Empirical models. Panel quantile regression is used to model the effects of covariates on the conditional quantiles of a response variable. Panel data models and quantile regression models are both widely used in applied econometrics of research in theoretical papers. The regression model established in this study is as shown below:

$$
\begin{aligned}
& C P_{i, t}=\beta_{0}+\sum_{i=1}^{7} \delta_{i, t} \times \text { Ownership_Structure }_{i, t}+ \\
& +\sum_{i=1}^{4} \lambda_{i, t} \times \text { Organize_Stabilize }_{i, t}+\varepsilon_{i} .
\end{aligned}
$$

The three corporate performance indices $(C P)$ mentioned above are represented with the abnormal return $(A R)$, return on equity $(R O E)$ and $\mathrm{P} / \mathrm{B}$ ratio $(P B R)$, respectively. These three dependent variables were used to examine the relationship of ownership structure and organization stability on corporate performance. Ownership structure includes the variables: manager stock holding $(M R H)$, natural persons' holding $(N P H)$, domestic financial institutions' holding $(L F I)$, foreign financial institutions' holding (FFIH), major shareholders holding $(M S H)$, board members' holding $(B M H)$, directors and supervisors' stock pledged ratio $(D S P)$, as well as organization stability represented board chairman turnover $(B C T)$, CEO turnover (CEOT), financial management turnover (FIT) and employment turnover rate $(E T R)$, to control other possible factors relating to corporate performance.

\section{Empirical result}

Based on the past literature, this is particularly true of quantile regression methods, since the linear programming algorithms that underlie reliable implementations of the methods appear somewhat esoteric to some users. The advantage of this methodology is that it decomposes the unconditional wage change at any quantile of the wage distribution. This study employs three corporate performance indices for the Taiwanese biotechnology stock: the abnormal return $(A R)$, return on equity $(R O E)$ and $\mathrm{P} / \mathrm{B}$ ratio $(P B R)$. Table 2 indicates that the smallest standard deviation between these indicators is the earning per share and the biggest is return of equity.

As to foreign financial institutions' holding $(F F I H)$, the mean is $73.427 \%$ as shown in Table 2 , where the maximum value reaches $101.711 \%$. This indicates a unique feature and importance of foreign investors

\begin{tabular}{|c|c|c|c|c|c|}
\hline Variables & Mean & Median & Max & Min & Std. \\
\hline \multicolumn{6}{|l|}{ Corporate performance } \\
\hline$A R$ & 0.792 & 0.553 & 24.121 & -16.018 & 2.476 \\
\hline ROE & -0.460 & 3.532 & 82.770 & -189.334 & 12.601 \\
\hline$P B R$ & -1.817 & 5.097 & 139.673 & -388.691 & 29.470 \\
\hline \multicolumn{6}{|l|}{ Ownership structure } \\
\hline MRH & 28.111 & 21.664 & 70.864 & 10.208 & 13.650 \\
\hline $\mathrm{NPH}$ & 4.290 & 0.000 & 53.007 & 0.000 & 10.639 \\
\hline$D F I$ & 19.713 & 15.822 & 52.250 & 0.978 & 11.095 \\
\hline FFIH & 73.427 & 71.938 & 101.711 & 3.364 & 19.510 \\
\hline$M S H$ & 2.039 & 1.129 & 12.838 & 0.000 & 2.380 \\
\hline$B M H$ & 5.352 & 0.048 & 75.004 & 0.000 & 10.587 \\
\hline$D S P$ & 1.455 & 0.000 & 15.659 & 0.000 & 2.737 \\
\hline
\end{tabular}
for the Taiwanese stock market.

Table 2. Descriptive statistics of variables 
Table 2 (cont.). Descriptive statistics of variables

\begin{tabular}{|l|c|c|c|c|c|}
\hline \multicolumn{1}{|c|}{ Variables } & Mean & Median & Max & Min & Std. \\
\hline Organization stability & 24.583 & 20.202 & 109.756 & 0.000 & 20.290 \\
\hline BCT & 20.357 & 16.545 & 91.700 & 0.000 & 16.576 \\
\hline CEOT & 22.393 & 18.199 & 100.807 & 0.000 & 18.233 \\
\hline FIT & 16.132 & 12.889 & 73.644 & 0.000 & 12.863 \\
\hline ETR &
\end{tabular}

The Pearson is correlation coefficient analysis, as shown in Table 3, suggests that all corporate performance, ownership structure and organization stability, except $N P H, M S H, B M H$, are positively correlated. Additionally, regarding the major shareholders holding, the $M S H$ value of $A R$ and
$R O E$, as well as $P B R$ of the Taiwan biotech pharmaceutical companies are significantly positively correlated. This suggests that the returns of the Taiwan biotech pharmaceutical companies will be higher positive, when the corporate performance index is $\mathrm{P} / \mathrm{B}$ ratio.

Table 3. Correlation analysis

\begin{tabular}{|c|c|c|c|c|c|c|c|c|c|c|c|c|c|c|}
\hline & $A R$ & $R O E$ & $P B R$ & $M R H$ & $\mathrm{NPH}$ & $D F I$ & FFIH & $M S H$ & $B M H$ & $D S P$ & $B C T$ & CEOT & FIT & ETR \\
\hline$A R$ & 1 & & & & & & & & & & & & & \\
\hline ROE & 0.901 & 1 & & & & & & & & & & & & \\
\hline$P B R$ & 0.754 & 0.720 & 1 & & & & & & & & & & & \\
\hline$M R H$ & 0.160 & 0.212 & 0.309 & 1 & & & & & & & & & & \\
\hline $\mathrm{NPH}$ & -0.010 & -0.011 & -0.086 & -0.272 & 1 & & & & & & & & & \\
\hline$D F I$ & 0.002 & 0.004 & -0.023 & -0.098 & 0.018 & 1 & & & & & & & & \\
\hline FFIH & 0.190 & 0.181 & 0.251 & 0.268 & -0.162 & 0.155 & 1 & & & & & & & \\
\hline$M S H$ & -0.267 & -0.213 & -0.212 & -0.162 & -0.090 & 0.048 & -0.144 & 1 & & & & & & \\
\hline$B M H$ & -0.016 & -0.048 & -0.105 & -0.504 & 0.224 & -0.078 & -0.374 & 0.067 & 1 & & & & & \\
\hline$D S P$ & 0.324 & 0.295 & 0.404 & 0.250 & -0.102 & 0.103 & 0.197 & -0.146 & -0.111 & 1 & & & & \\
\hline$B C T$ & 0.126 & 0.180 & 0.235 & 0.284 & 0.099 & 0.067 & 0.197 & -0.130 & -0.004 & 0.083 & 1 & & & \\
\hline CEOT & 0.090 & 0.125 & 0.198 & 0.255 & 0.093 & -0.008 & 0.233 & -0.164 & 0.015 & 0.068 & 0.865 & 1 & & \\
\hline FIT & 0.051 & 0.067 & 0.048 & 0.184 & 0.003 & -0.002 & 0.051 & -0.055 & 0.065 & 0.020 & 0.402 & 0.346 & 1 & \\
\hline ETR & -0.221 & -0.230 & -0.004 & 0.093 & -0.013 & 0.190 & 0.058 & 0.242 & -0.081 & 0.077 & 0.177 & 0.111 & 0.223 & 1 \\
\hline
\end{tabular}

The model establishes a behavior-based link between corporate performance and ownership structure. The estimations of conditional quantile regression models based on a panel dataset of Taiwan's listed companies during 2004 and 2015 confirm the predictions of this theory. Table 4 and Table 5 show that, for every quantile, the effect of foreign financial institutions' holding $(F F I H)$ and board members' holding $(B M H)$ are significantly positive to both abnormal return and return of equity, indicating that foreign financial institutions' holding as an indicator of performance by Taiwan biotechindustry, the same as to board members' holding. On the other hand, the preliminary data illustrate that the employment turnover rate and the returns of Taiwan biotech pharmaceutical companies are reversely correlated.

Table 4. The results of quantile regression on abnormal return $(A R)$

\begin{tabular}{|c|c|c|c|c|c|c|}
\hline & OLS & $1 \mathrm{QR}$ & $3 Q R$ & $5 \mathrm{QR}$ & $7 \mathrm{QR}$ & $9 \mathrm{QR}$ \\
\hline \multirow{2}{*}{ MRH } & $0.003^{\star \star \star}$ & 0.002 & 0.003 & $0.004^{\star \star *}$ & $0.005^{\star \star \star}$ & 0.001 \\
\hline & $(0.001)$ & $(0.002)$ & $(0.001)$ & $(0.001)$ & $(0.001)$ & $(0.001)$ \\
\hline \multirow{2}{*}{$\mathrm{NPH}$} & 5.873 & 0.000 & 0.000 & 6.092 & 0.000 & 0.001 \\
\hline & 0.000 & $(0.001)$ & $(0.001)$ & $(0.001)$ & $(0.001)$ & $(0.001)$ \\
\hline \multirow{2}{*}{$D F I$} & 0.000 & 0.001 & 0.001 & 0.000 & 0.001 & 0.002 \\
\hline & $(0.001)$ & $(0.002)$ & $(0.001)$ & $(0.001)$ & $(0.001)$ & $(0.001)$ \\
\hline \multirow{2}{*}{$\mathrm{FFIH}$} & $0.003^{\star \star \star}$ & $0.005^{\star \star \star}$ & $0.006^{\star \star \star}$ & $0.005^{\star \star \star}$ & $0.004^{\star \star \star}$ & $0.005^{\text {*** }}$ \\
\hline & $(0.001)$ & $(0.002)$ & $(0.001)$ & $(0.001)$ & $(0.001)$ & $(0.001)$ \\
\hline \multirow{2}{*}{$M S H$} & 0.003 & 0.001 & 0.006 & 0.003 & 0.001 & 0.002 \\
\hline & $(0.004)$ & $(0.012)$ & $(0.007)$ & $(0.004)$ & $(0.003)$ & $(0.008)$ \\
\hline \multirow{2}{*}{$B M H$} & $0.002^{* \star *}$ & $0.006^{* * *}$ & $0.015^{* \star *}$ & $0.003^{* * *}$ & $0.003^{* * *}$ & $0.002^{* *}$ \\
\hline & $(0.001)$ & $(0.001)$ & $(0.001)$ & $(0.001)$ & $(0.000)$ & $(0.001)$ \\
\hline \multirow{2}{*}{$D S P$} & 0.019 & 0.035 & 0.024 & 0.024 & 0.019 & 0.005 \\
\hline & $(0.063)$ & $(0.079)$ & $(0.075)$ & $(0.093)$ & $(0.082)$ & $(0.092)$ \\
\hline \multirow{2}{*}{$B C T$} & 0.001 & $0.007^{* \star *}$ & 0.004 & 0.001 & 0.000 & 0.002 \\
\hline & $(0.002)$ & $(0.002)$ & $(0.002)$ & $(0.002)$ & 0.002 & 0.003 \\
\hline
\end{tabular}


Table 4 (cont.). The results of quantile regression on abnormal return $(A R)$

\begin{tabular}{|l|c|c|c|c|c|c|}
\hline & OLS & $1 \mathrm{QR}$ & $3 \mathrm{QR}$ & $5 \mathrm{QR}$ & $7 \mathrm{QR}$ & $9 \mathrm{QR}$ \\
\hline \multirow{2}{*}{ CEOT } & 0.002 & $-0.009^{* *}$ & 0.006 & 0.002 & 0.000 & 0.003 \\
\cline { 2 - 7 } & $(0.003)$ & $(0.003)$ & $(0.004)$ & $(0.003)$ & $(0.002)$ & $(0.004)$ \\
\hline \multirow{3}{*}{$F I T$} & 0.024 & 0.010 & 0.015 & 0.025 & 0.040 & 0.045 \\
\cline { 2 - 7 } & $(0.098)$ & $(0.127)$ & $(0.135)$ & $(0.102)$ & $(0.063)$ & $(0.091)$ \\
\hline \multirow{3}{*}{ ETR } & 0.038 & 0.740 & 0.193 & 0.039 & 0.087 & 0.067 \\
\hline \multirow{2}{*}{$C$} & $(0.094)$ & $(0.429)$ & $(0.179)$ & $(0.098)$ & $(0.083)$ & $(0.150)$ \\
\cline { 2 - 8 } & $-0.294^{* *}$ & $-0.517^{* * *}$ & $-0.269^{* *}$ & -0.185 & -0.195 & 0.062 \\
\cline { 2 - 7 } & $(0.076)$ & $(0.139)$ & $(0.098)$ & $(0.079)$ & $(0.058)$ & $(0.100)$ \\
\hline
\end{tabular}

Note: The variables are manager stock holding $(M R H)$, natural persons' holding $(N P H)$, domestic financial institutions' holding $(D F I)$, foreign financial institutions' holding $(F F I H)$, major shareholders holding $(M S H)$, board members' holding $(B M H)$, directors and supervisors' stock pledged ratio $(D S P)$, double leverage ratios $(D L R)$, long-term to total assets ratio $(L T A)$, degree of financial leverage $(D F L)$ and agency costs $(A C)$. The notations of ***,** and * denote statistical significance at $1 \%, 5 \%$, and $10 \%$ levels.

Table 5. The results of quantile regression on return of equity $(R O E)$

\begin{tabular}{|c|c|c|c|c|c|c|}
\hline & OLS & $1 \mathrm{QR}$ & $3 Q R$ & $5 \mathrm{QR}$ & $7 \mathrm{QR}$ & $9 Q R$ \\
\hline \multirow{2}{*}{ MRH } & 0.047 & 0.049 & 0.042 & 0.051 & 0.028 & 0.029 \\
\hline & $(1.761)$ & $(1.789)$ & $(1.623)$ & $(1.914)$ & $(1.090)$ & $(1.099)$ \\
\hline \multirow{2}{*}{$\mathrm{NPH}$} & 0.041 & 0.035 & -0.021 & -0.039 & 0.010 & -0.070 \\
\hline & $(0.031)$ & $(0.079)$ & $(0.058)$ & $(0.052)$ & $(0.060)$ & $(0.099)$ \\
\hline \multirow{2}{*}{$D F I$} & 0.048 & 0.029 & 0.068 & 0.031 & -0.039 & -0.120 \\
\hline & $(0.208)$ & $(0.124)$ & $(0.065)$ & $(0.055)$ & $(0.049)$ & $(0.074)$ \\
\hline \multirow{2}{*}{$F F I H$} & $0.088^{\star \star *}$ & $0.499^{* \star *}$ & $0.354^{\star \star *}$ & $0.248^{\star \star \star}$ & $0.290^{* * *}$ & $0.288^{\star \star \star}$ \\
\hline & $(0.245)$ & $(0.174)$ & $(0.108)$ & $(0.094)$ & $(0.089)$ & $(0.133)$ \\
\hline \multirow{2}{*}{$M S H$} & 0.288 & 0.101 & 0.008 & 0.009 & 0.009 & 0.008 \\
\hline & $(0.150)$ & $(0.701)$ & $(0.719)$ & $(0.321)$ & $(0.298)$ & $(0.455)$ \\
\hline \multirow{2}{*}{$B M H$} & $0.051^{* \star *}$ & $0.354^{* * *}$ & $0.287^{* \star *}$ & $0.177^{* \star *}$ & $0.139^{* \star *}$ & 0.091 \\
\hline & $(1.245)$ & $(0.177)$ & $(0.041)$ & $(0.071)$ & $(0.047)$ & $(0.075)$ \\
\hline \multirow{2}{*}{$D S P$} & 0.006 & 0.005 & 0.006 & 0.006 & 0.006 & 0.005 \\
\hline & $(0.634)$ & $(0.621)$ & $(0.477)$ & $(0.583)$ & $(0.591)$ & $(0.605)$ \\
\hline \multirow{2}{*}{$B C T$} & 0.044 & 0.045 & 0.048 & 0.051 & 0.045 & 0.046 \\
\hline & $(1.321)$ & $(1.321)$ & $(1.425)$ & $(1.568)$ & $(1.393)$ & $(1.405)$ \\
\hline \multirow{2}{*}{ CEOT } & -0.045 & -0.007 & -0.052 & 0.055 & 0.054 & $-0.106^{*}$ \\
\hline & $(-0.990)$ & $(-0.121)$ & $(-1.112)$ & $(1.086)$ & $(1.256)$ & $(-2.244)$ \\
\hline \multirow{2}{*}{ FIT } & -0.009 & -0.007 & -0.007 & -0.008 & -0.007 & -0.008 \\
\hline & $(-0.498)$ & $(-0.626)$ & $(-0.499)$ & $(-0.641)$ & $(-0.547)$ & $(-0.599)$ \\
\hline \multirow{2}{*}{ ETR } & 0.019 & 0.017 & 0.013 & 0.266 & 0.229 & 0.241 \\
\hline & $(0.507)$ & $(0.569)$ & $(0.561)$ & $(0.999)$ & $(0.997)$ & $(1.001)$ \\
\hline \multirow{2}{*}{$C$} & $0.299^{* \star *}$ & $0.381^{* * *}$ & $0.296^{* * *}$ & $0.272^{\star \star \star}$ & $0.293^{\star \star *}$ & $0.196^{* \star}$ \\
\hline & $(5.266)$ & $(6.456)$ & $(5.253)$ & $(4.411)$ & $(5.128)$ & (3.201) \\
\hline
\end{tabular}

Note: The variables are manager stock holding $(M R H)$, natural persons' holding $(N P H)$, domestic financial institutions' holding $(D F I)$, foreign financial institutions' holding $(F F I H)$, major shareholders holding $(M S H)$, board members' holding $(B M H)$, directors and supervisors' stock pledged ratio $(D S P)$, double leverage ratios $(D L R)$, long-term to total assets ratio $(L T A)$, degree of financial leverage $(D F L)$ and agency costs $(A C)$. The notations of $* * *, * *$ and $*$ denote statistical significance at $1 \%, 5 \%$, and $10 \%$ levels.

Furthermore, according to the Table 6 , the results show that the ownership structure and the organization stability have a positive effect on firm performance. In addition, regarding employment turnover rate $(E T R)$, the value is -7.393 and is negatively correlated to the returns of $\mathrm{P} / \mathrm{B}$ ratio $(P B R)$. Quantile regression goes beyond this and enables one to pose such a question at any quantile of the conditional distribution function. Foreign financial institutions holding $(F F I H)$ was identified as significant predictor for PBR at any quantile.

Table 6. The results of quantile regression on $\mathrm{P} / \mathrm{B}$ ratio $(P B R)$

\begin{tabular}{|c|c|c|c|c|c|c|}
\hline \multirow{2}{*}{$P B R$} & OLS & 1 QR & $3 Q R$ & 5 QR & 7 QR & $9 Q R$ \\
\hline \multirow{2}{*}{$M R H$} & 0.069 & 0.020 & 0.120 & $0.243^{* * *}$ & $0.218^{* \star *}$ & 0.087 \\
\cline { 2 - 7 } & $(0.041)$ & $(0.134)$ & $(0.082)$ & $(0.076)$ & $(0.063)$ & $(0.099)$ \\
\hline \multirow{2}{*}{$N P H$} & 0.046 & 0.033 & -0.019 & -0.042 & 0.004 & -0.077 \\
\cline { 2 - 7 } & 0.032 & $(0.081)$ & $(0.056)$ & $(0.057)$ & $(0.062)$ & $(0.096)$ \\
\hline
\end{tabular}


Table 6 (cont.). The results of quantile regression on $\mathrm{P} / \mathrm{B}$ ratio $(P B R)$

\begin{tabular}{|c|c|c|c|c|c|c|}
\hline$P B R$ & OLS & $1 \mathrm{QR}$ & $3 Q R$ & $5 Q R$ & $7 \mathrm{QR}$ & $9 Q R$ \\
\hline \multirow{2}{*}{$D F I$} & 0.050 & 0.022 & 0.064 & 0.033 & -0.048 & -0.113 \\
\hline & $(0.211)$ & $(0.123)$ & $(0.069)$ & $(0.051)$ & $(0.056)$ & $(0.078)$ \\
\hline \multirow{2}{*}{ FFIH } & $0.079^{\star \star *}$ & $0.502^{* \star \star}$ & $0.321^{\star * *}$ & $0.243^{\star \star *}$ & $0.2814^{\star * *}$ & $0.2118^{\star \star *}$ \\
\hline & $(0.244)$ & $(0.164)$ & $(0.098)$ & $(0.080)$ & $(0.088)$ & $(0.128)$ \\
\hline \multirow{2}{*}{ MSH } & 0.295 & -0.748 & -0.395 & -0.249 & -0.358 & -0.139 \\
\hline & $(0.155)$ & $(0.721)$ & $(0.781)$ & $(0.302)$ & $(0.293)$ & $(0.551)$ \\
\hline \multirow{2}{*}{$B M H$} & $0.049^{* \star *}$ & $0.348^{* * *}$ & $0.200^{\star \star *}$ & $0.159^{\star * \star}$ & $0.128^{\star \star \star}$ & 0.084 \\
\hline & $(1.060)$ & $(0.107)$ & $(0.061)$ & $(0.050)$ & $(0.039)$ & $(0.071)$ \\
\hline \multirow{2}{*}{$D S P$} & 0.001 & -0.001 & 0.001 & 0.001 & 0.001 & 0.001 \\
\hline & $(0.010)$ & $(-0.041)$ & $(0.139)$ & $(0.235)$ & $(0.121)$ & $(0.119)$ \\
\hline \multirow{2}{*}{$B C T$} & 0.118 & $0.619^{\star \star}$ & 0.181 & -0.025 & -0.144 & -0.245 \\
\hline & $(0.009)$ & $(0.203)$ & $(0.219)$ & $(0.120)$ & $(0.086)$ & $(0.147)$ \\
\hline \multirow{2}{*}{ CEOT } & -0.202 & $-0.643^{* *}$ & -0.329 & 0.009 & 0.157 & 0.242 \\
\hline & $(1.905)$ & $(0.309)$ & $(0.327)$ & $(0.206)$ & $(0.146)$ & $(0.244)$ \\
\hline \multirow{2}{*}{ FIT } & -6.118 & 3.263 & -0.500 & -1.947 & -2.835 & -3.009 \\
\hline & $(5.296)$ & $(11.605)$ & $(12.048)$ & $(6.250)$ & (3.694) & $(5.033)$ \\
\hline \multirow{2}{*}{ ETR } & $-7.393^{\star \star \star}$ & $-70.470^{\star * *}$ & -15.042 & -5.408 & 3.701 & 14.314 \\
\hline & $(7.635)$ & (26.685) & $(14.920)$ & $(7.553)$ & (8.687) & (11.533) \\
\hline \multirow{2}{*}{ C } & $-5.400^{* * *}$ & $-32.156^{* *}$ & -14.299 & -9.675 & -4.016 & 6.465 \\
\hline & $(0.069)$ & (10.977) & (8.688) & $(5.517)$ & $(4.583)$ & (8.201) \\
\hline
\end{tabular}

Note: The variables are manager stock holding $(M R H)$, natural persons' holding $(N P H)$, domestic financial institutions' holding $(D F I)$, foreign financial institutions' holding $(F F I H)$, major shareholders holding $(M S H)$, board members' holding $(B M H)$, directors and supervisors' stock pledged ratio $(D S P)$, double leverage ratios $(D L R)$, long-term to total assets ratio $(L T A)$, degree of financial leverage $(D F L)$ and agency costs $(A C)$. The notations of $* * *, * *$ and $*$ denote statistical significance at $1 \%, 5 \%$, and $10 \%$ levels.

\section{Conclusion}

The remarkable development of market capital depends on the transparency of market information. The empirical results can be summarized as follows. In this paper we use the method of quantile regression to analysis the effect of different ownership structure and organization stability on the performance of the biotechnology company. Data from the 2004 and 2015 Taiwan listed biotechnology companies are the research samples to find out the relationship of ownership structure, organization stability and corporate performance.

According to the findings of this study, the result finds that the ownership structure and the organization stability have a positive effect on firm performance. Therefore, the corporate governance plays a role by Taiwan biotech companies. This study further explores and provides useful insights and practical implications for investors to examine the value of the biotechnology company.

\section{References}

1. Ang, J., R. Cole and J. Lin. (1999). Agency Costs and Ownership Structure, Journal of Finance, 55, pp. 81-106.

2. Barnhart, S.W. and S. Rosenstein. (1998). Board Composition Managerial Ownership and Firm Performance: an Empirical Analysis, The Financial Review, 33, pp. 1-16.

3. Black, B.S., H. Jang and W. Kim. (2003). Does Corporate Governance Affect Firm Value? Evidence from Korea, The Journal of Law Economics and Organization, 22, p. 2.

4. Canay, I. (2011). A Simple Approach to Quantile Regression for Panel Data, Econometrics Journal, 14, pp. 368-386.

5. Cerbionia, F. and A. Parbonettia (2007). Exploring the Effects of Corporate Governance on Intellectual Capital Disclosure: An Analysis of European Biotechnology Companies, European Accounting Review, 16, pp. 791-826.

6. Chernozhukov, V., I. Fern_andez-Val, J. Hahn, and W. Newey. (2013). Supplement to Average and Quantile Effects in Nonseparable Panel Models, Econometrica, 81, pp. 535-580.

7. Han, K.C. and D.Y. Suk. (1998). The Effect of Ownership Structure on Firm Performance: Additional Evidence, Review of Financial Economics, 7, pp. 143-154.

8. Harjoto, M. and H. Jo. (2011). Corporate Governance and CSR Nexus, Journal of Business Ethics, 100, pp. 45-67.

9. He, X., J. Zhang, J. Wang. (2015). Market Seeking Orientation and Performance in China: The Impact of Institutional Environment, Subsidiary Ownership Structure and Experience, Management International Review, 55, pp. 389-419.

10. Kelton, A.S. and Y.W. Yang. (2008). The Impact of Corporate Governance on Internet Financial Reporting, Journal of Accounting and Public Policy, 27, pp. 62-87.

11. Kim, H.R., M. Lee, H.T. Lee and N.M. Kim. (2010). Corporate Social Responsibility and Employee - Company Identification, Journal of Business Ethics, 95, pp. 557-569. 
12. Koenker, R., Bassett, G. (1978). Regression Quantiles, Econometrica, 46, pp. 33-50.

13. Lacetera, N. (2001). Corporate Governance and the Governance of Innovation: The Case of Pharmaceutical Industry, Journal of Management and Governance, 5, pp. 29-59.

14. Litvak, K. (2007). The Effect of the Sarbanes - Oxley Act on non -US Companies Crosslisted in the US, Journal of Corporate Finance, 13, pp. 195-228.

15. McConnell, J.J. and H. Servaes. (1990). Additional Evidence on Equity Ownership and Corporate Value, Journal of Financial Economics, 27, pp. 595-612.

16. McConnell, J.J., H. Servaes and K.V. Lins. (2008). Changes in Insider Ownership and Changes in the Market Value of the Firm, Journal of Corporate Finance, 14, pp. 92-106.

17. Minor, D. and J. Morgan. (2011). CSR as Reputation Insurance: Primum Non Nocere, California Management Review, 53, pp. 157-159.

18. Porta, L.R., F. Lopez-de-Silanes and A. Shleifer. (1999). Corporate Ownership Around the World, Journal of Finance, 54, pp. 471-517.

19. Rechner, P.L. and D.R. Dalton. (1991). CEO Duality and Organization Performance: A Longitudinal Analysis, Strategic Management Journal, 12, pp. 155-260.

20. Roger, K. and B. Gilbert. (1978). Regression Quantiles, Econometrica, 46 (1), pp. 33-50.

21. Singh, M. and W.N. Davidson. (2003). Agency Costs Ownership Structure and Corporate Governance Mechanisms, Journal of Banking and Finance, 27, pp. 793-816.

22. Teresa, M.P. and W.J. Gilbert. (2011). Corporate Governance and Board Equity Ownership, Corporate Governance, 11, pp. 200-213.

23. Villalonga, B. and R. Amit. (2006). How Do Family Ownership, Control Andmanagement Affect Firm Value? Journal of Financial Economics, 80, pp. 385-417.

24. Weir, C., D. Laing and P.J. McKnight. (2002). Internal and ExtemalGovemance Mechanisms: Their Impact on the Performance of Large UK Public Companies, Jounal of Business Finance and Accounting, 29, pp. 579-611.

25. Yeh, Y.H. and T. Woidtke. (2005). Commitment or Entrenchment?: Controlling Shareholders and Board Composition, Journal of Banking and Finance, 29, pp. 1857-1885. 